Molecules 2002, 7, 501-506

molecules

ISSN 1420-3049

http://www.mdpi.org

\title{
Carotamine, a Unique Aromatic Amide from Daucus Carota L. Var Biossieri (Apiaceae)
}

\author{
Omayma A. Eldahshan, Nahla A. Ayoub*, Abd-El Naser B. Singab and Mohamed M. El-Azizi. \\ Department of Pharmacognosy, Faculty of Pharmacy, Ain-Shams University, Cairo, Egypt.
}

*Author to whom correspondence should be addressed; e-mail: ayoub.n@link.com.eg

Received: 11 May 2002; in revised form: 24 June 2002 / Accepted 26 June 2002/ Published: 30 June 2002

\begin{abstract}
The unique aromatic peptide 4-( $p$-aminobenzoylamino)-2-aminobenzoic acid, carotamine, together with 2,4-diaminobenzoic acid, isolated for the first time from a plant source, were identified from the aqueous alcoholic extract of the aerial parts of Daucus carota L. var. boissieri (Apiaceae). The structures were determined through conventional methods of analysis and confirmed by LC-ESI/MS and NMR spectral analysis.
\end{abstract}

Keywords: Daucus carota L. var boissieri (Apiaceae); aromatic peptide; 4-( $p$-amino benzoylamino)-2-aminobenzoic acid; aminoacids; 2,4-diaminobenzoic acid

\section{Introduction}

Daucus L. (Apiaceae) [1] includes about 60 species distributed mostly in Europe, Africa, West Asia and few ones in North America and Australia [2]. In Egypt, the genus Daucus L. is represented by 6 wild species [1] among which the two varieties Daucus carota boissieri [3] and Daucus carota sativus [4] are widely cultivated for their fleshy edible roots (Bailey, 1960). Daucus carota has been reported to contain several constituents such as flavonoids [6,7], essential oils [8,9], polyacetylenes [10,11] and phenylpropanoids [12]. Daucus carota is well known in the Egyptian folk medicine as a stimulant, carminative and diuretic [13]. The decoction of carrot is used for infantile diarrhoea and as an antihelmentic [14]. The fruit essential oil has been proven to be hypotensive, cardiac and CNS 
depressant [15], antibacterial [16], antibilharzial [17], and fungicidal [18]. Carrots also showed a significant protective activity in the alleviation of chloroform-induced hepatocellular injury in the mouse [19].

The present study reports on the isolation and identification of 2,4-diaminobenzoic acid (1) and the unique aromatic peptide, 4-( $p$-aminobenzoylamino)-2-aminobenzoic acid (2) or carotamine, which is the first aromatic peptide reported to occur in nature. Extensive EI and LC-ESI/MS techniques were applied together with ${ }^{1} \mathrm{H}$ - and ${ }^{13} \mathrm{C}-\mathrm{NMR}$ spectral analysis to verify the full structure of both compounds.

\section{Results and discussion}

The aqueous alcoholic extract of the ground meal of the aerial Daucus carota parts, dried under vacuum, was defatted through exhaustive extraction with $\mathrm{CHCl}_{3}$. The residue left after $\mathrm{CHCl}_{3}$ extraction was shown by two-dimensional chromatography to contain a mixture of polar compounds (high $R_{f}$ values in aqueous solvents and low $R_{f}$ values in organic solvent) mainly of phenolic nature (positive $\mathrm{FeCl}_{3}$ test). The chromatograms also revealed the presence of two non-polar compounds that under UV light appeared as canary yellow (compound 1) and dark purple (compound 2) spots, respectively. A combination of column chromatography on Sephadex LH-20, using water saturated butanol as an eluent and preparative paper chromatography using 6\% acetic acid as solvent afforded two pure samples of compounds $\mathbf{1}$ and $\mathbf{2}$.

Compound 1 was isolated as an amorphous white powder with LC/UV absorption maxima at 227, 274 and $312 \mathrm{~nm}$. The IR spectral analysis revealed two intense absorption bands at $v_{\max } 3449.9$ and $1661.7 \mathrm{~cm}^{-1}$, consistent with amino and hydroxyl groups and a carbonyl group, respectively. The EI/MS gave a molecular ion at m/z 152. In LC-ESI-ve/MS (see Experimental) compound 1 exhibited a $\mathrm{R}_{\mathrm{t}}$ of $3.48 \mathrm{~min}$. and a molecular ion at $\mathrm{m} / \mathrm{z} \mathrm{151}$, corresponding to a molecular weight of 152 . Under Collision Induced Dissociation (CID) conditions fragment ions at m/z 135, 108 and 91 have been observed and are attributed to the $[\mathrm{M}-\mathrm{NH} 3]^{-},[\mathrm{M}-\mathrm{COO}]^{-}$and $\left[\mathrm{M}-\left(\mathrm{NH}_{2}+\mathrm{COO}\right)\right]^{-}$ions, respectively. The above given data suggest a diaminobenzoic acid structure for compound $\mathbf{1}$. To resolve any ambiguity about the structure of $\mathbf{1},{ }^{1} \mathrm{H}$ and ${ }^{13} \mathrm{C}-\mathrm{NMR}$ spectral analysis were then undertaken. The ${ }^{1} \mathrm{H}-\mathrm{NMR}$ spectrum (DMSO- $d_{6}$, room temperature) revealed, in the aromatic region, the presence of a resonance pattern at $\delta 6.3(d, J=2 \mathrm{~Hz}), 6.4(d d, J=2 \mathrm{~Hz} \& J=7.5 \mathrm{~Hz})$ and $7.8(d, J=7.5 \mathrm{~Hz})$ ppm, typical of a 1,2,4trisubstituted benzene [20], and assigned to H-3, H-5 and H-6 in the proposed 2,4-diaminobenzoic acid structure of (1). The spectrum also revealed a downfield resonance appearing as a sharp singlet at $\delta$ $12.7 \mathrm{ppm}$ attributable to a hydrogen bonded proton (between the carbonyl carboxyl group at position 1 and the $o$-amino group at position 2, thus confirming the structure of (1) as 2,4-diaminobenzoic acid. Further confirmation of the structure was obtained through ${ }^{13} \mathrm{C}-\mathrm{NMR}$ analysis. The recorded spectrum showed seven distinct aromatic carbon resonances among which the most downfield resonance at $\delta$ $168.0 \mathrm{ppm}$ was assigned to the carboxyl carbon resonance while the most upfield resonance at $\delta 100.1$ ppm was assigned to the quaternary C-1 carbon. Assignment of the remaining carbon resonances was 
aided by calculating the expected chemical shifts deduced by applying the additive substituent rules to the reported chemical shifts of anthranilic acid [21]. Consequently, the carbons that bear the amino groups, C-2 and C-4, were found resonating at $\delta 148.9$ and $152.6 \mathrm{ppm}$, respectively. The protonated carbons C-3, C-5 and C-6 gave three signals at $\delta 103.2,108.5$ and $134.1 \mathrm{ppm}$, respectively, which all agree well with the 2,4-diaminobenzoic acid structure proposed for 1 . It should be mentioned that this is the second reported natural occurrence of this compound, which has been characterised once before as a metabolite of Streptomyces flocculus [22].

Compound 2 was isolated as an amorphous yellow powder which exhibited in its LC/UV spectrum two fused absorption maxima at 363.8 and $336 \mathrm{~nm}$ as well as two shoulders at 237 and $302 \mathrm{~nm}$. IR spectral analysis of 2 afforded a spectrum which revealed three absorption bands at $v_{\max } 3445.7$, 1659.9 and $1640.5 \mathrm{~cm}^{-1}$, consistent with amino and hydroxyl groups, a carboxyl carbonyl group and an amide carbonyl group, respectively. Standard alkaline hydrolysis $\left(5 \%\right.$ aqueous $\mathrm{KOH}, 100^{\circ} \mathrm{C}, 1 / 2$ hour) of compound 2 yielded 2,4-diaminobenzoic acid (1) and $p$-aminobenzoic acid (CoPC). The EI/MS of 2 showed a molecular ion at m/z 271 and a base peak at 270, thus suggesting that the molecule of 2 is formed by two amino acids joined by an amide linkage (also detected by alkaline hydrolysis). In this spectrum the base peak at $\mathrm{m} / \mathrm{z} 270$ is therefore due to the loss of a carboxylic hydrogen or allylic proton from the amide bridge. The LC-ESI-ve/MS of 2 exhibited a $\mathrm{R}_{\mathrm{t}}$ of $5.2 \mathrm{~min}$. (see Experimental) and a molecular ion at $\mathrm{m} / \mathrm{z} 270$ corresponding to a molecular weight of 271 . Under CID conditions the spectrum showed fragment ions at $\mathrm{m} / \mathrm{z} 135,120,91$ attributable to [aminobenzoic acid]', [aminobenzoic acid- $\mathrm{OH}]^{-}$and $\left[\mathrm{M}-\left(\mathrm{NH}_{2}+\mathrm{COO}\right)\right]^{-}$, respectively. The spectrum also showed a significant fragment ion at $\mathrm{m} / \mathrm{z} 254$ assignable to $\left[\mathrm{M}-\mathrm{NH}_{3}\right]^{-}$which also confirms that compound $\mathbf{2}$ is composed of 2,4-diaminobenzoic acid and monoaminobenzoic moieties linked through an amide bond. The results of ${ }^{1} \mathrm{H}-\mathrm{NMR}$ spectral analysis of 2 lent further support to its suggested structure. The spectrum (DMSO$d_{6}$, room temperature) showed distinct five proton resonances in the aromatic region at $\delta 6.4(d, J=2.5$ $\mathrm{Hz}), 6.5(d d, J=2.5$ and $7.5 \mathrm{~Hz})$ and $7.8(d, J=7.5 \mathrm{~Hz}) \mathrm{ppm}$, respectively, corresponding to the 2,4diaminobenzoic acid and at $7.1(d, J=7.5 \mathrm{~Hz})$ and $8.2(d, J=7.5 \mathrm{~Hz}) \mathrm{ppm}$, assignable to H-3', H-5' and to H-2', H-6' in the symmetrical p-aminobenzoyl moiety. More interesting is the presence in this spectrum of a highly downfield sharp singlet resonance at $12.7 \mathrm{ppm}$, attributable to a hydrogen bonded proton. This reflected the presence of an unsubstituted $\mathrm{COOH}$ group at position 1 (see below) as well as the presence of a free vicinal amino group at position 2, responsible for the formation of the recognized hydrogen bond. Consequently, the structure of $\mathbf{2}$ is proven to be 4 -( $p$-aminobenzoylamino)2 -aminobenzoic acid. Further support of this structure was then achieved through ${ }^{13} \mathrm{C}$-NMR spectral analysis (DMSO- $\mathrm{d}_{6}$, room temperature) whereby the two most downfield resonances in the spectrum at $\delta 168.2$ and $164.6 \mathrm{ppm}$ are obviously due to the free carboxyl carbonyl carbon $(\mathrm{C}-7)$ and to the amide carbonyl carbon (C-7'). The most two intense resonances at $\delta 115.0$ and $131.3 \mathrm{ppm}$ are attributable to the C-3', C-5' and C-2', C-6' in the symmetrical p-aminobenzoyl moiety of 2. Aromatic carbons bearing nitrogen functions (C-2, C-4 and C-4') appeared at $\delta$ 148.3, 154.4 and 153.1 ppm, respectively. The other carbon resonances in this spectrum exhibited chemical shift values which 
agreed well with the proposed structure of 2 as 4-( $p$-aminobenzoylamino)-2-aminobenzoic acid, a new natural product.<smiles>Nc1ccc(C(=O)O)c(N)c1</smiles>

(1)<smiles>Nc1ccc(C(=O)Nc2ccc(C(=O)O)c(N)c2)cc1</smiles>

(2)

\section{Acknowledgements}

The authors are deeply indebted to Dr. J. Hau, Nestlé Research Center, Nestec Ltd., Vers-chez-lesBlanc, P.O.Box 44, CH-1000 Lausanne 26, Switzerland, for the LC-ESI/MS measurements.

\section{Experimental}

\section{General}

LC/MS analyses were performed by reversed-phase HPLC on a Purosphere STAR RP-18

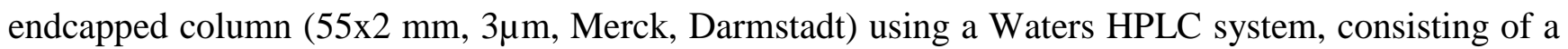
Waters 2690 "Alliance" separation module coupled to a Waters 996 scanning UV detector. Flow injection analysis was performed by injecting $10 \mu$ of the extract into a solvent stream of methanol/water (1:1 by volume). Solvent A was $100 \%$ acetonitrile (HPLC grade, Merck); solvent B was water. Elution was performed at room temperature and at flow rate of $0.8 \mathrm{~mL} / \mathrm{min}$. The gradient program started at 5\% A with an isocratic hold for $3 \mathrm{~min}$, followed by a fast linear increase to $95 \% \mathrm{~A}$ at $4 \mathrm{~min}$. The solvent composition was held for $1 \mathrm{~min}$ to flush the column, then changed back to initial conditions over $1 \mathrm{~min}$ and equilibrated for $4 \mathrm{~min}$ before the next sample injection; a shorter equilibration time lead to a shift in retention times. The total run time was $10 \mathrm{~min}$. The eluent of the HPLC was split at a 1:4 ratio using an AcuRate ${ }^{\text {TM }}$ flow splitter (LC Packings, via Omnilab, Mettmenstetten, $\mathrm{CH}$ ) so that approximately $200 \mu /$ min entered the electrospray ion source of the mass spectrometer. The mass spectrometer used in this study was a Micromass Quattro-LC triple quadrupole mass spectrometer equipped with a "Z-Spray" electrospray ion source. The electrospray capillary 
voltage was set to $3.0 \mathrm{kV}$, the source block temperature to $120^{\circ} \mathrm{C}$. The cone gas was operated at $60 \mathrm{I} / \mathrm{h}$, desolvation gas at $520 \mathrm{I} / \mathrm{h}$ and the desolvation temperature to $150^{\circ} \mathrm{C}$. Spectra were acquired in profile mode alternating with 35 and $70 \mathrm{~V}$ cone voltage and scanning over the range $\mathrm{m} / \mathrm{z} 50$ to 1500 per second. Data acquisition was performed using Micromass'software package MassLynx 3.4. ${ }^{1} \mathrm{H}-$ and ${ }^{13} \mathrm{C}$-NMR spectra were obtained on a Bruker AMX 400 spectrometer. ${ }^{1} \mathrm{H}$ spectra were measured relative to TMS and ${ }^{13} \mathrm{C}$ spectra were measured at $100 \mathrm{MHz}$, relative to DMSO- $\mathrm{d}_{6}$ and converted to the TMS scale by adding 77 ppm. Paper chromatography (PC) was carried out on Whatman No. 1 paper, using either (1) $\mathrm{H}_{2} \mathrm{O}$; (2) $6 \% \mathrm{HOAc}$ or (3) BAW (n-BuOH-HOAc- $\mathrm{H}_{2} \mathrm{O}$, 4:1:5, top layer) as eluents; solvent 2 was used for preparative PC (PPC) on Whatman No. $3 \mathrm{~mm}$ paper.

\section{Plant material, isolation and identification}

Fresh aerial parts of Daucus carota L. var boissieri, were collected from Orman Botanical garden, Cairo, Egypt, during March 2000 and authenticated by Prof. Dr. Nabil El-Hadidi, Department of Botany, Faculty of Science, Cairo University, Egypt. A voucher specimen has been deposited in the Herbarium of the Faculty of Pharmacy, Ain-Shams University, Cairo, Egypt. One kg of aerial parts of Daucus carota, dried in the shade in an air-draft, were comminuted to powder and exhaustively extracted with EtOH- $\mathrm{H}_{2} \mathrm{O}$ (3:1). The aqueous alcoholic extract was dried in vacuum, and completely defatted with $\mathrm{CHCl}_{3}$. The residue left, $10 \mathrm{~g}$, was dissolved in methanol and subjected to column chromatography (CC) on Sephadex LH-20 using $n$ - $\mathrm{BuOH}$ saturated with $\mathrm{H}_{2} \mathrm{O}$ for elution to yield 10 major fractions (I-X). Compound (1) (15 mg) was isolated from fraction IV by repeated PPC using $6 \%$ HOAc as a solvent. Compound (2) (20 mg) was obtained from fraction $\mathbf{X}$ by PPC using 6\% HOAc as a solvent followed by Sephadex LH-20 CC using MeOH for elution.

\section{2,4-Diaminobenzoic acid (1).}

$\mathrm{R}_{\mathrm{f}}$-values: $0.55\left(\mathrm{H}_{2} \mathrm{O}\right), 0.60$ (HOAc), 0.45 (BAW); LC/UV $\lambda_{\max }(\mathrm{nm}): 227,274$ and 312; IR $v_{\max }$ $\mathrm{cm}^{-1}: 3449.9,1661.7 ; M_{\mathrm{r}}$ 152, -ve ESI/MS [M-H] ${ }^{-}: 151 ;{ }^{1} \mathrm{H}-\mathrm{NMR}: \delta$ ppm $6.3(d, J=2.5 \mathrm{~Hz}, \mathrm{H}-3), 6.4$ $(d d, J=7.5 \mathrm{~Hz}$ and $J=2.5 \mathrm{~Hz}, \mathrm{H}-5), 7.8(d, J=7.5 \mathrm{~Hz}, \mathrm{H}-6) ;{ }^{13} \mathrm{C}-\mathrm{NMR}: \delta$ ppm $100.1(\mathrm{C}-1), 148.9(\mathrm{C}-$ 2), 103.2 (C-3), 152.6 (C-4), 108.5 (C-5), 134.1 (C-6), 168.0 (C-7).

4-(p-Aminobenzoylamino)-2-aminobenzoic acid (2).

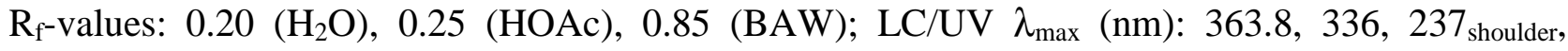
$302_{\text {shoulder; }}$ IR $v_{\max } \mathrm{cm}^{-1}: 3445.7,1659.9,1640.5 ; M_{\mathrm{r}} 271$, -ve ESI/MS [M-H] $: 270 ;{ }^{1} \mathrm{H}-\mathrm{NMR}: \delta \mathrm{ppm}$ $6.4(d, J=2.5 \mathrm{~Hz}, \mathrm{H}-3), 6.5$ (dd, $J=7.5$ and $2.5 \mathrm{~Hz}, \mathrm{H}-5), 7.1$ (d, J = 7.5, H-3' \& H-5'), 7.8 (d, $J=7.5$ $\mathrm{Hz}, \mathrm{H}-6), 8.2\left(d, J=7.5\right.$, H-2'\& H-6’); ${ }^{13} \mathrm{C}-\mathrm{NMR}: \delta$ ppm 100.5 (C-1), $148.3(\mathrm{C}-2), 103.5(\mathrm{C}-3), 154.4$ (C-4), 108.5 (C-5), 133.1 (C-6), 168.2 (C-7), 118.8 (C-1'), 131.3 (C-2'), 115.0 (C-3'), 153.1 (C-4'), 115.0 (C-5'), 131.3 (C-6'), 164.6 (C-7'). 


\section{References}

1. Täckholm, Vv. Student Flora of Egypt; Cairo University Press: Cairo, 1972, p193.

2. Jafri, S.M.H. Flora of Libya; 1. Ed.: Al Faateh University, Faculty of Science: Libya, 1985, p130.

3. Muschler, R. A Manual Flora of Egypt; R. Friedlander and Sons: Berlin, 1912; Vol. II, p 711.

4. Tutin, T.G.; Heywood, V.H.; Burges, N.A.; Moore, D.M.; Valentine, D.H.; Walters, S.M.; Webb, D.A. Flora Europaea; Cambridge University Press: Cambridge, 1981; Vol II, p 373.

5. Bailey, L.H. Manual of Cultivated Plants Growing in the United States and Canada; MacMillan: New York, 1960, p 747.

6. El Sayed, N.H.; El-Kubesy, T.M. Biochem. Syst. Ecol., 1994, 22, 762.

7. Singab, A.B.; Masuda, Y.; Okada, Y.; Mahran, G.; Khalifa, T.; Okuyama, T. Nat. Med., 1996, 49.

8. Kilibarda, V.; Nanusevic, N.; Dogovic, N.; Ivanic, R.; Savin, K. Pharmazie 1996, 51, 777.

9. Porchezhian, E.; Ansari, S.H.; Ali, M. Ind. J. Nat. Prod., 2000, 61, 24.

10. Lund, E.D. Phytochemistry 1992, 31, 3621.

11. Degen, T.; Buser, H.-R.; Stadler, E. J. Chem. Ecol., 1999, 25, 67.

12. Nagahashi, G.; Abney, C.D.; Doner, L.W. New Phytol., 1996, 133, 281.

13. El-Antaki, D. Tazkaret Oly-Al Albab; 3. Ed.; El-Azharia Press: Cairo, 1923, p122.

14. Watt, J.M.; Breyer, M.J. The Medicinal and Poisonous Plants of Southern and Eastern Africa; E. and S. Livingstone: London, 1962, p134.

15. Bodrug, M.V. Status and Prospects of Study and Use of Aromatic Plants in the Moldavian-SSR; USSR: Rastit, Resuur, 1982, p 558.

16. Syed, M.; Sabir, A.W.; Chaudhary, F.M.; Bhatly, M.K. Pak. J. Sci. Ind. Res., 1986, 29, 189.

17. Halim, A.F.; Mashaly, M.M.; Sandra, P. $1^{\text {st }}$ Anglo-Egyptian Conference of Pharm. Sci., Alexandria, Egypt, Nov, 1988, p15.

18. Dwivedi, S.K.; Pandey, V.N.; Dubey, N.K. Flavour Frag. J., 1991, 6, 295.

19. Bishayee, A.; Sarkar, A.: Chatterjee, M. J. Ethnopharmacol., 1995, 37, 69.

20. Hesse, M.; Meier, H.; Zeeh, B. Spectroscopic Methods in Organic Chemistry; George Thieme Verlag: Stuttgart, New York, 1997, p123.

21. Kalinowiski, H.O.; Berger, S.; Braum, S. ${ }^{13}$ C-NMR Spektroskopie; Georg Thieme Verlag: Stuttgart, New York, 1984.

22. Gould, S.J. J. Antibiotics, 1988, 41, 688.

Sample availability: Available from the authors.

(C) 2002 by MDPI (http://www.mdpi.org). Reproduction is permitted for noncommercial purposes. 